\title{
Variation of ribosomal DNA and inheritance of polymorphisms in 6 Petunia hybrida hort lines
}

\author{
F Zeboudj ${ }^{1}$, A Kabbaj ${ }^{1 \dagger}$, K Sossey Alaoui ${ }^{1 \dagger}$, D Peltier ${ }^{1}$, A Tagmount ${ }^{1 \dagger}$, \\ C Raquin 2, M Darmency 1, D Maizonnier 1, H Dulieu 1, A Bervillé 1† \\ 1 INRA-Dijon, station de génétique et d'amélioration des plantes, BV 1540, F21034 Dijon cedex; \\ ${ }^{2}$ Université de Paris-Sud, centre d'Orsay, bât 360, laboratoire d'amélioration des plantes, F91405 Orsay cedex 05, France;
}

(Received 23 April 1994; accepted 21 October 1994)

\begin{abstract}
Summary - Ribosomal DNA polymorphisms were studied in 6 lines of Petunia hybrida using EcoRI, BamHI, Hindll, $\mathrm{Kpnl}$, Sacl or Xhol. Each line carries several unit types, and 13 types were found in lines, which was not expected. We characterized the unit types and we determined the number of loci. Two kinds of unit types carrying no or several Hindlll sites were revealed. The longest $E c o R I$ and BamHI fragments in St43 correspond to a $11.4 \mathrm{~kb}$ unit type. Moreover, a $2.6 \mathrm{~kb} E c o R \mathrm{I}$ fragment cannot be mapped in the $11.4 \mathrm{~kb}$ unit. It was found to be equivalent to the $2.45 \mathrm{~kb}$ EcoRl fragment carrying the $25 \mathrm{~S}$ rRNA coding sequence. Consequently, it was mapped in another unit $11.7 \mathrm{~kb}$ long. In Tlh1 the corresponding EcoRI and BamHI fragments enabled us to construct 8.8, 9.2 and $10.8 \mathrm{~kb}$ segments. These fragments are therefore considered to be part of the $11.4 \mathrm{~kb}$ unit length. Other lines display combinations of these length units. The inheritance of polymorphic fragments of lines (St43 and Tlh1) for 50 individuals of the 2 possible backcrosses [(St43 $\times$ Tlh1) $\times$ St43] and [(St43 $\times$ Tlh1) $\times$ Tlh1] indicated at least 2 loci. The presence in Sk176 of 6.2, 5.7 and 5.4 EcoRI fragments suggested 3 loci. The haploid plants obtained from the hybrid (St43 $\times$ Tlh1) display 1 individual carrying the 3 unit types present in the hybrid which proves the presence of 3 rDNA loci in Th1. Moreover, the segregation in the backcrosses corresponds to only 2 loci in St43. It carries a nulli-allele. Evidence for such hypotheses were obtained by in situ hybridization with a biotinylated probe. The TIh1 and TIh7 dihaploid lines display more unit types and, consequently, more polymorphisms than other lines.
\end{abstract}

\section{Petunia hybrida / ribosomal DNA / inheritance / in situ hybridization}

Résumé - Variation de l'ADN ribosomique et hérédité du polymorphisme dans 6 lignées de Petunia hybrida Hort. Dans 6 lignées de Petunia hybrida dont l'ADN a été hydrolysé par EcoRl, BamHI, Hind/II, Kpnl, Sacl ou Xhol, I'ADN ribosomique est apparu très polymorphe. Chaque lignée porte plusieurs types d'unités; ainsi 13 types différents sont révélés dans les lignées, ce qui est surprenant. Nous avons caractérisé les différents types et déterminé le nombre de loci. Deux types d'unités avec et sans sites Hind'Il sont révélés. Pour la lignée St43 les fragments EcoRl et BamHI permettent de construire une unité de 11,4 kb. En outre un fragment $\mathrm{EcoRl}$ de 2,6 kb ne peut être placé dans l'unité de $11,4 \mathrm{~kb}$. II est en effet équivalent au fragment de $2,4 \mathrm{~kb}$ portant la séquence codante du gène $25 \mathrm{~S}$. II est donc placé dans une unité de $11,7 \mathrm{~kb}$. Dans la lignée Th 1 les fragments correspondants ne permettent de construire que des unités de $8,8 \mathrm{~kb}, 9,2 \mathrm{~kb}$, et $10,8 \mathrm{~kb}$, donc considérées comme une partie d'unités de 11,4 kb. Les autres lignées montrent une combinaison des fragments précédents. L'hérédité du polymorphisme dans 50 descendants du couple de lignées (St43 et Tih1) et les 2 rétrocroisements possibles [(St43 $\times$ Tlh1) $\times$ St43] et [(St43 $\times$ Tlh1) $\times$ Tlh1]

\footnotetext{
* Correspondence and reprints; ${ }^{\dagger}$ present address: INRA-ENSAM, station d'amélioration des plantes, 2, place P-Viala, F34060
} Montpellier cedex 1, France 
indique au moins 2 loci. La présence dans $S k 176$ des fragments EcoRI 6,2, 5,7 et 5,4 suggère 3 loci. Parmi les plantes haploïdes obtenues de l'hybride F1 (St43 x Tlh1), un descendant porte les 3 types d'unité présents dans l'hybride, ce qui ne peut s'expliquer que s'ils sont répartis sur 3 loci. De plus la ségrégation dans les rétrocroisements correspond à 2 loci pour St43, il porte donc un nulliallèle. La confirmation des hypothèses est apportée par hybridation in situ avec une sonde ribosomique biotinylée. Les 2 lignées dihaplö̈des Tlh1 et Tih7 montrent le plus d'unités et par conséquent le polymorphisme le plus élevé.

\section{Petunia hybrida / ADN ribosomique / hérédité / PLFR / hybridation in situ}

\section{INTRODUCTION}

Petunia hybrida is a model species for genetic studies. More than 100 traits have been studied so far (Cornu et al, 1990). Only a few molecular markers, allozymes and restriction fragment length polymorphisms (RFLP) have been used for obtaining such a map. In order to increase the number of assigned markers, we studied the RFLP within the rDNA, in the lines used in crosses St43 $\times$ Thlh1 and Sk176b $\times$ St 43 (Cornu et al, 1989), another couple St40 and Tlv1 (Cornu et al, 1990), and the Mitchell line (here named Tlh7) which has already been studied by Waldron et al (1983) for rDNA organization and unit types. Moreover, the rDNA is associated with the chromosome carrying the nucleolar organiser (NOR) usually associated with a satellite (Arnheim et al, 1980), and hence chromosome II and chromosome III of $P$ hybrida might be good candidates for carriers of the rDNA of these loci since they both carry satellites (Maizonnier, 1976).

The inheritance of rDNA fragments and consequently of rDNA unit types has been shown to be of the Mendelian type as expected for codominant markers (Saghai Maroof et al, 1984; Ellis et al, 1988). One rDNA locus has been found in the tomato (Levesque et al, 1990). Two rDNA loci have been found in barley (Saghai Maroof et al, 1984), in wheat (May and Appels, 1987), peas (Ellis et al, 1984), maize (Rocheford et al, 1990) and sunflower (Voronina, 1991). Moreover, improved varieties and cultivars of maize, soybean and sugar beet displayed less variability than wild species because of a homogenization mechanism working on a few unit types or length variant types (Doyle et al, 1990; Rocheford et al, 1990; Santoni and Bervillé, 1992). Consequently, the rDNA variability in $P$ hybrida is expected to be reduced in comparison with that of the wild forms or species from which it originated.

The rDNA polymorphism in the 6 lines was found to be unexpectedly high. Eleven different unit types were found in 6 lines. This fact sug- gests that the rDNA variation existed before $P$ hybrida was created 170 years ago (Wijsman, 1982). According to the sorting of rDNA unit types in 3 different backcrosses, we concluded that at least 2 loci carry rDNA units. Nevertheless, since we did not cross a couple of lines carrying 3 different unit types, the possible third locus was verified with haploid plants. Indeed, the sorting of rDNA unit types in haploid plants from the St $43 \times$ TIh1 hybrid corresponds to 3 loci. Therefore as 2 of the loci probably corresponded to the 2 chromosomes carrying satellites, in situ hybridizations were carried out on both metaphasic chromosomes from root tips and on prophase 1 of pollen mother cell (PMC) meiotic chromosomes. Two and 3 loci were revealed for St43 and TIh1, respectively. Two loci corresponded to the chromosomes carrying a satellite; the third locus remains to be assigned.

\section{MATERIAL AND METHODS}

\section{Plant material}

The plant material is described in table I. Plant growth occurred in a growth chamber $\left(20^{\circ} \mathrm{C}\right.$ for $16 \mathrm{~h}$ during the day and $15^{\circ} \mathrm{C}$ during the night) where all crosses were carried out.

\section{DNA preparation}

DNA was prepared from the young leaves of 2-3month-old plants according to Bernatsky and Tanksley (1986). All other conditions for electrophoresis, Southern transfer, prehybridation, hybridization, and rinsing of filters have been described previously by Santoni and Bervillé (1992).

\section{Probes}

We used the $8.2 \mathrm{~kb}$ entire flax rDNA unit pBG35 (Goldsbrough and Cullis, 1981). This was kindly pro- 
Table I. List of the main traits and origin of plant material.

\begin{tabular}{lll} 
Line & Flower colour & Origin \\
\hline & & \\
St43 & Violet pink & R43 (IGA) \\
Tlh1 & Clear violet, dihaploid line & Haploid TL67 \\
Sk176b & Clear pink & Satin rouge \\
Tlv1 & Clear violet & TL $\times$ Sg \\
Tlh7 & Violet white, dihaploid line & Rose du Ciel $\times$ P axillaris \\
St40 & Clear pink & R40 (IGAa)
\end{tabular}

a IGA: Institute of Genetics, Amsterdam, the Netherlands

vided by $\mathrm{N}$ Ellis. A sub-clone of the unit corresponds to the central part of the $25 \mathrm{~S}$ rRNA coding sequence (pRH83). The $6.1 \mathrm{~kb}$ EcoRl fragment $(6.1 \mathrm{~kb}$ probe) and a $1050 \mathrm{bp}$ sub-clone (kindly provided by $P$ Heizmann) correspond to the IGS and to the almost complete $18 \mathrm{~S}$ rRNA coding sequence of sunflower, respectively (Choumane and Heizmann, 1988). They were further designated as $8.2 \mathrm{~kb}, 6.1 \mathrm{~kb}, 25 \mathrm{~S}$ rDNA or $18 \mathrm{~S}$ rDNA probes.

For in situ hybridization the $8.2 \mathrm{~kb}$ fragment was labelled with the 'bioNick Labeling System' from Bethesda Research Laboratories MD, USA.

\section{Obtention of haploid plants}

The method for nucleus substitution using gamma-rayinduced androgenesis has been previously described for Petunia hybrid lines (Raquin et al, 1989). In situ hybridizations were performed on chromosome spreads according to Maizonnier and Moessner (1979). We also used a haploid plant obtained spontaneously from the line St43.

\section{RESULTS}

\section{Construction of ribosomal DNA physical maps}

The total DNA of each line was restricted either by EcoRI, BamHI, Sacl, Kpnl, Pstl, Xhol or HindlII. The double digests were obtained by pairwise combination of these enzymes. We did not reveal any $K p n l$ sites in major unit types, therefore the double EcoRI/Kpnl digests were equivalent to EcoRI digests for the major fragments. The Southern transfers were sequentially hybridized with the $18 \mathrm{~S}$ rDNA, the $25 \mathrm{~S}$ rDNA and the $8.2 \mathrm{~kb}$ unit as probes. We also used the $6.1 \mathrm{~kb}$ fragment as a probe. Because of $\mathrm{C}$ and $\mathrm{A}$ methylation we have considered that unit types were not distinguished with a restriction enzyme sensitive to methylation.

\section{rDNA physical maps in St43}

A $7.9 \mathrm{~kb}$ EcoRl fragment was detectable on the hybridization patterns of St 43 DNA with the $6.1 \mathrm{~kb}$ probe (fig 1A). Two EcoRl fragments of 2.45 and $2.6 \mathrm{~kb}$ were hybridized with the $8.2 \mathrm{~kb}$ and $25 \mathrm{~S}$ rDNA probes (fig 1B, D, lane EK). The 2.45 and $2.6 \mathrm{~kb}$ EcoRl fragments were cut by BamHI leading to a $2 \mathrm{~kb}$ fragment resulting from partial hydrolysis of the 1.2 and $0.8 \mathrm{~kb}$, hybridized with the $25 \mathrm{~S}$ rDNA only (fig 1D). Moreover, another EcoRl fragment of $1.1 \mathrm{~kb}$ was revealed with the $8.2 \mathrm{~kb}$ as a probe (fig $1 \mathrm{~B}$, lane EK). This fragment was not detected previously by Waldron et al (1983) and was regularly outside of the gel used to separate the largest fragments. The $1.1 \mathrm{~kb}$ EcoRI fragment was not cut by BamHI (fig 1B, lane EB). The line also carried the $1.2 \mathrm{~kb} \mathrm{BamHl}$ fragment hybridizing with the $25 \mathrm{~S}$ rDNA (fig 1D, lane $\mathrm{BH}$ ) and the $2.7 \mathrm{~kb} \mathrm{BamHI}$ fragment hybridizing with the $18 \mathrm{~S}$ rDNA or the $25 \mathrm{~S}$ rDNA probes (fig $1 \mathrm{~A}$ ). The 1.1 and $1.8 \mathrm{~kb}$ $\mathrm{Sacl}$ fragments hybridized with the $18 \mathrm{~S}$ rDNA and the $25 \mathrm{~S}$ rDNA, respectively (not shown). The $0.9 \mathrm{BamHI}$ and $1.8 \mathrm{~kb} \mathrm{Sacl}$ fragments are cut by Xhol (not shown).

These results were interpreted in the construction of the physical map of the rRNA coding sequences (fig 2). The length of the unit is $7.9+$ $1.1+2.45=11.45 \mathrm{~kb}$ with $E c o R l$ and $6.8+0.9+$ $2.7+1.2=11.6 \mathrm{~kb}$ with BamHI. Nevertheless, the $2.6 \mathrm{~kb} E \mathrm{CoRI}$ fragment was not assigned in this map. Because of its weak intensity, we suspect that it corresponds to a minor unit type carrying all the other fragments and is therefore 11.6 $\mathrm{kb}$ long. According to densitometric analyses, it 

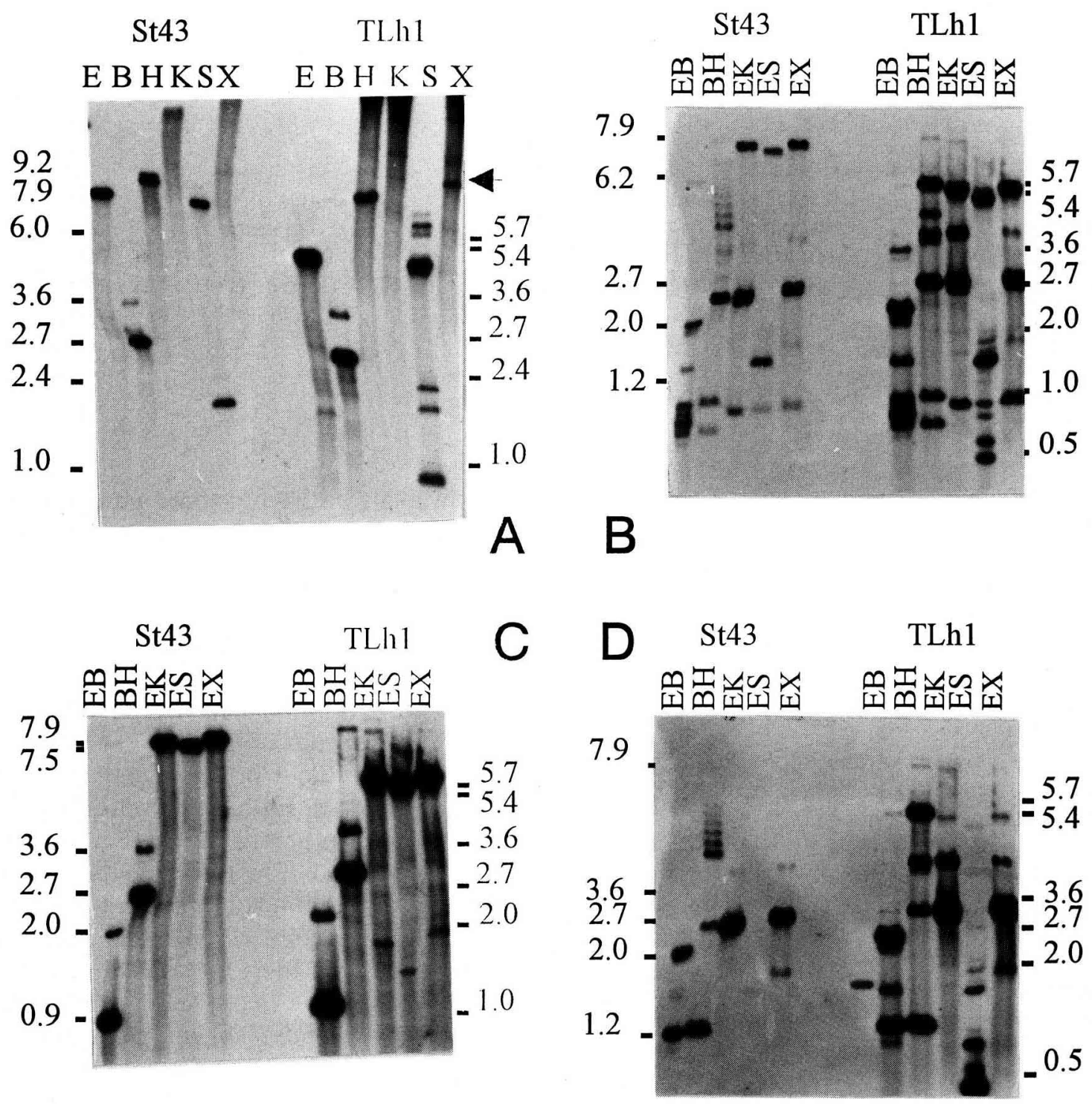

Fig 1. Hybridization profiles of $\mathrm{St} 43$ and TIh1 DNAs restricted by $\mathrm{E}=\mathrm{EcoRI}, \mathrm{B}=\mathrm{BamHI}, \mathrm{H}=$ Hindll, $\mathrm{K}=\mathrm{Kpnl}, \mathrm{S}=\mathrm{Sacl}, \mathrm{X}=\mathrm{Xhol}$ or pairwise combination, eg, $\mathrm{EX}=E c \mathrm{RI}+\mathrm{Xhol}$. Size of fragments are in $\mathrm{kb}$. A: with the $6.1 \mathrm{~kb}$ fragment of sunflower as a probe; $\mathrm{B}$ : with the $8.2 \mathrm{~kb}$ fragment of flax as a probe; $\mathbf{C}$ : with $18 \mathrm{~S}$ rDNA as a probe; D: with $25 \mathrm{~S} \mathrm{rDNA}$ as a probe. The size of fragments was determined with the $1 \mathrm{~kb}$ ladder from Bethesda Research Laboratories as a reference.

corresponds to $24 \%$ of the rDNA types (table II). There was a difference of $0.15 \mathrm{~kb}$ between the 2.45 and $2.6 \mathrm{~kb}$ fragments located between B1 and $E 1$, thus no other fragments carrying the 25 $S$ rRNA coding region were found to be variable in length.

When cut with Hindll, 2 fragments of 9.2 and $8.8 \mathrm{~kb}$ were revealed with the $8.2 \mathrm{~kb}$ probe (fig 1B). The double BamHI-Hindll digest led to a ladder of fragments between 4.1 and $6.3 \mathrm{~kb}$, plus a $3.5 \mathrm{~kb}$ fragment which, taken all together, suggested the presence of several Hindll sites ( $\mathrm{H} 1$ to $\mathrm{H} 5$ ) spaced at about $0.4 \mathrm{~kb}$. The $\mathrm{H} 6$ site was
Table II. Densitometric analysis of the $2-4 \mathrm{~kb}$ region on hybridization profiles of St 43 DNA with the $8.2 \mathrm{~kb}$ rDNA entire unit from flax as a probe.

\begin{tabular}{cccc}
$\begin{array}{c}\text { Fragment size } \\
(\mathrm{kb})\end{array}$ & $\begin{array}{c}\text { Peak location } \\
(\mathrm{mm})\end{array}$ & Area & $\begin{array}{c}\text { Relative } \\
\text { area }^{\mathrm{a}}\end{array}$ \\
\hline 2.45 & 85.04 & 2.6164 & 75.7 \\
2.6 & 82.72 & 0.8400 & 24.3
\end{tabular}

a Ratio $=3.11$. 
$0.6 \mathrm{~kb}$ away from H5 (fig 1B, D; fig 2). Therefore, the 2 fragments revealed 2 unit types which differ only by the $\mathrm{H} 6$ site. The Xhol pattern of $\mathrm{St} 43$ displayed a $9.4 \mathrm{~kb}$ fragment hybridized by the 3 probes and the $1.2 \mathrm{~kb}$ fragments which hybridized with the $25 \mathrm{~S}$ rDNA only (not shown).

\section{Physical maps in other lines}

The characterization of the rDNA unit types in all lines depends on the EcoRI and BamHI fragments carrying the IGS (table III). The lengths of these fragments enable the determination of the
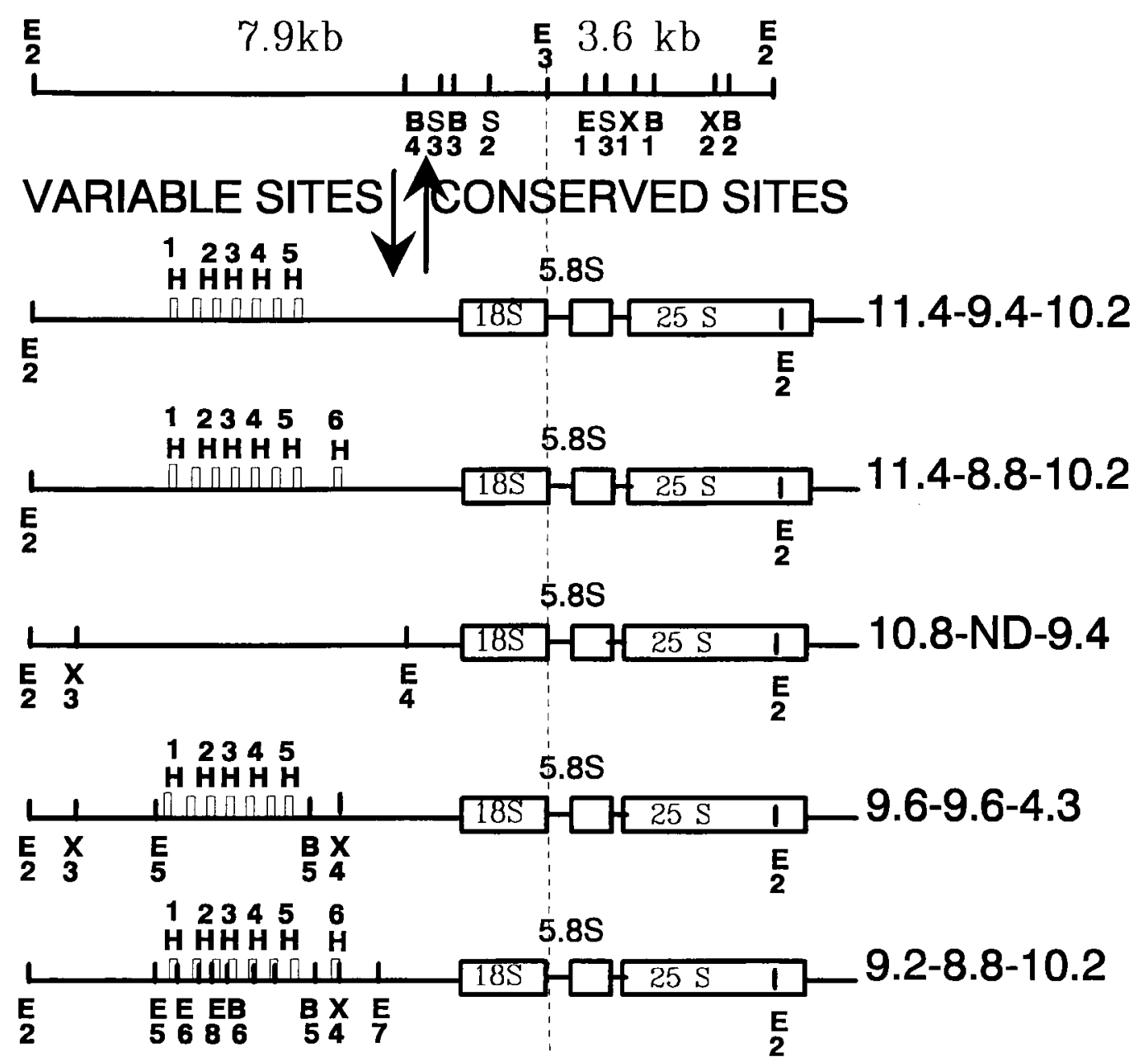

$5.8 S$

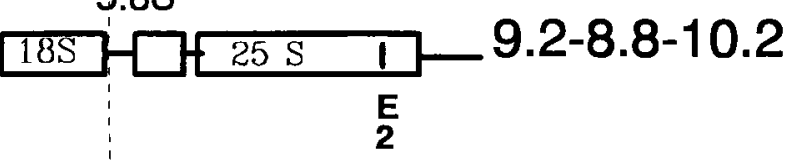

123456

$\mathrm{H} \mathrm{HHH} \mathrm{H} \mathrm{H}$
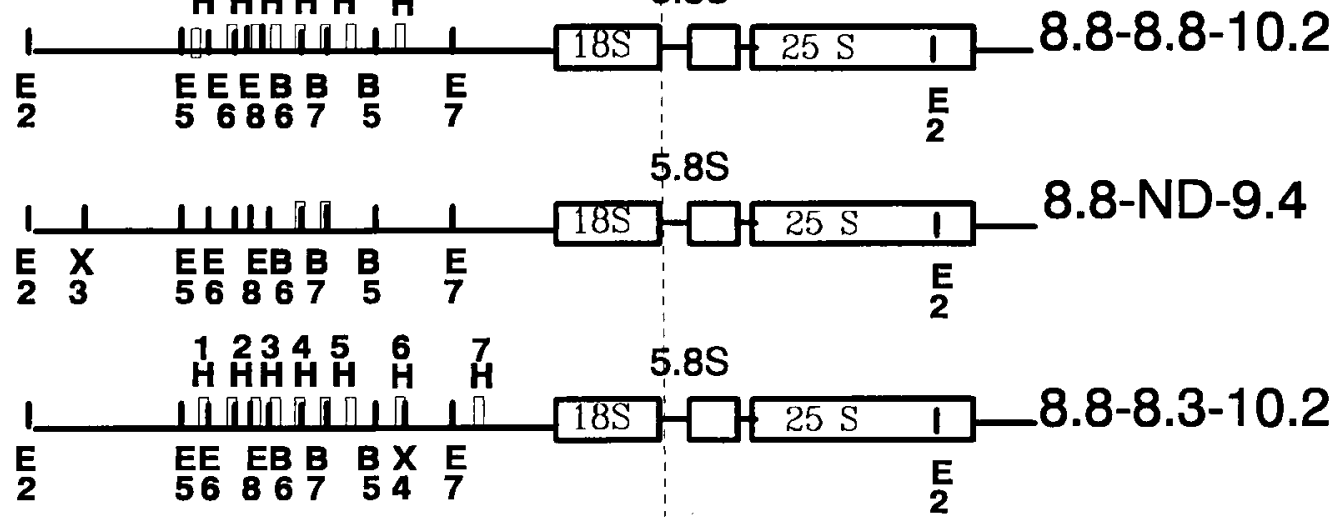

Fig 2. Physical maps of 8 rDNA unit types present in the $6 P$ hybrida lines, $\mathrm{E}=\mathrm{EcoRI}, \mathrm{B}=\mathrm{BamHI}, \mathrm{H}=\mathrm{Hindll}, \mathrm{S}=\mathrm{Sacl}, \mathrm{X}=\mathrm{Xhol}$. The scale and the position of the coding sequences are indicated at the top and then by a box. The maps are aligned on $E 3=$ the dotted vertical line. The series of the 6 Hindll sites $(1-6)$ and $H 7$ are indicated by a hollow bar above the line. The sites are numbered according to the order in which they were found in the different lines. The other 5 unit types are easily deduced according to the following code: $11.4-9.4-10.2$ means: $11.4-=$ the longest EcoRI-BamHI region, $-9.4-=$ the Hindll fragment or ND = no Hindll site, -10.2 = the Xhol fragment; 11.4-9.4-9.4 = 11.4-9.4-10.2 + X3; 11.4-9.2-9.4 = 11.4-9.4-9.4 + H8, 0.2 kb away from H5; 9.5-9.5-4.2 $=9.6-9.6-4.3$ with a $0.1 \mathrm{~kb}$ deletion in the IGS between X4 and E4; 9.2-ND-10.2 = 9.2-8.8-9.4 with X3 without the series of H1 to H6 sites; 8.8-8.8-9.4 and 8.8-8.8-9.6 are equivalent to 8.8-8.8-10.2 with X3 and X'3 $0.2 \mathrm{~kb}$ away from $X 3$ position. 
Table III. Unit types displayed by the 6 lines and arbitrary assignment to 3 loci.

$\begin{array}{lccc}\text { Lines } & \text { Locus 1 } & \text { Locus 2 } & \text { Locus 3 } \\ & & & \\ \text { St43 } & 11.4-9.4-10.2 & 11.4-8.8-10.2 & \\ \text { Tlh1 } & 8.8-8.8-9.6 & 9.2-N D-9.4 & 10.8-N D-9.4 \\ \text { Sk176b } & 9.2-8.8-10.2 & 9.6-9.6-4.3 & 8.8-8.8-9.4 \\ \text { Tlv1 } & 9.2-N D-9.4 & 11.4-9.2-9.4 & 10.8-N D-9.4 \\ \text { St40 } & 9.2-N D-9.4 & 10.8-N D-9.4 & 11.4-8.8-9.4 \\ \text { Tlh7 } & 8.8-8.3-10.2 & 9.5-9.5-4.2 & 9.6-9.6-4.3 \\ & 8.8-N D-9.4 & 9.2-N D-9.4 & \end{array}$

11.4-, 10.8-, 9.6-, 9.2- and 8.8- unit types are recognized by $7.9,5.7,4.9,4.5,4.1 \mathrm{~kb}$ EcoRI and $6.8,5.4,4.2,3.8$ and $3.4 \mathrm{~kg} \mathrm{BamHI}$ fragments, respectively.

longest EcoRI-BamHI region. Moreover, Hindll restriction of St43 DNA was complete while it was incomplete for Th1 DNA, due to the presence of a unit type without Hindll sites (fig 1A). $X$ hol restriction showed that the longest fragment hybridizing with the $8.2 \mathrm{~kb}$ probe was about 11.4 kb $(10.2+1.2)$, which corresponds to a whole unit (fig $1 \mathrm{~A}$, arrow). Consequently, the unit types were labelled according to the length of the longest region or fragment obtained with EcoRI and $\mathrm{BamHI}$, Hindll, or Xhol. The total length unit was either 11.45 or $11.6 \mathrm{~kb}$ (table III).

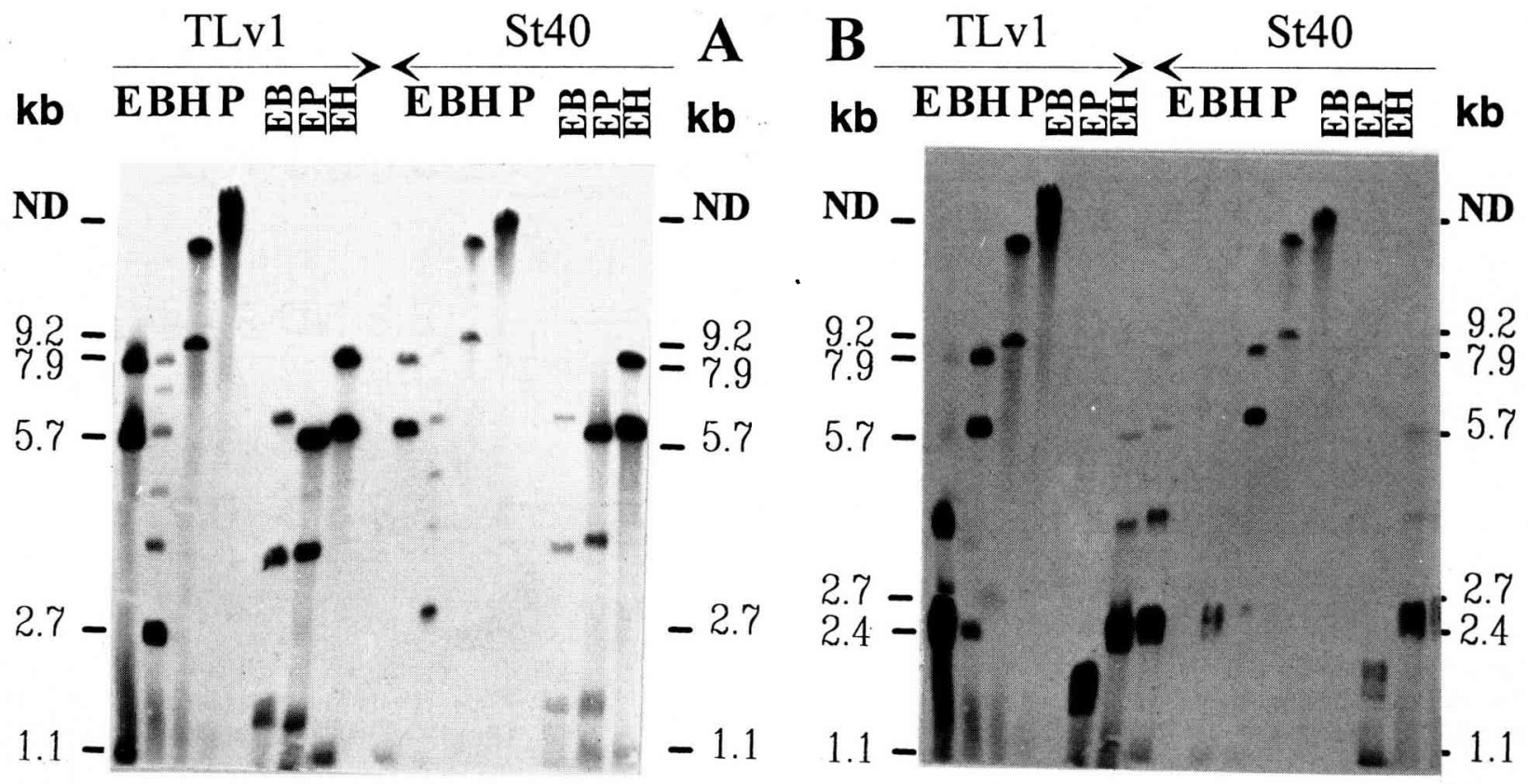

\section{rDNA physical maps in St40 and TIv1}

These lines displayed the $7.9 \mathrm{~kb} E c o R I$ fragment, but TIv1 also displayed the $9.2 \mathrm{~kb}$ Hindll fragment, St40 showed the $8.8 \mathrm{~kb}$, and both lines displayed the $9.4 \mathrm{~kb}$ Xhol fragment. Tlv1 carried the 11.4-9.2-9.4, and St 40 the 11.4-8.8-9.4 unit types, which have both been described previously in St43. Moreover, the lines carried a minor $1.6 \mathrm{~kb}$ EcoRI fragment hybridized with the $18 \mathrm{~S}$ rDNA, presumably attached to a $5.7 \mathrm{~kb} E c o \mathrm{RI}$ fragment revealed with the entire unit as a probe, and a $6 \mathrm{~kb} \mathrm{BamHl}$ fragment (fig 3). This unit type was designated as 10.8-ND-9.4, since the probes did not hybridize with any Hindll fragments, which means that there is no Hindll site in the units. With Xhol, a $9.4 \mathrm{~kb}$ fragment hybridized with all the probes (not shown).

\section{rDNA physical maps in Tlh1, Sk176b and TIh7}

Tlh1 carried the $1.6 \mathrm{~kb} E c o \mathrm{Rl}$ and the $4.6 \mathrm{~kb}$ $\mathrm{BamHI}$ fragments corresponding to the 10.8-ND-9.4 unit type. Moreover, it displayed the 5.4 EcoRI, $4.0 \mathrm{~kb} \mathrm{BamHI,} 5.7 \mathrm{~kb}$ EcoRI, $4.6 \mathrm{~kb} \mathrm{BamHI}$ and $8.8 \mathrm{~kb}$ Hindll fragments only. With $X$ hol, a fragment of $9.4 \mathrm{~kb}$ was present. Therefore it carried the 8.8-8.8-9.4 and the 9.2-ND-9.4 unit types (fig 1). The Hindll digest of Sk176b DNA displayed 2 fragments of 8.8 and $9.6 \mathrm{~kb}$ while the $X$ hol digest displayed the $10.2 \mathrm{~kb}$ and a $4.3 \mathrm{~kb}$ fragment. Two EcoRl frag-

Fig 3. Hybridization profiles of $\mathrm{St} 40$ and Tlv1 DNAs restricted by $\mathrm{E}=\mathrm{EcoRI}, \mathrm{B}=\mathrm{BamHI}, \mathrm{H}=$ HindII, $\mathrm{P}=$ Pstl or pairwise combination. Size of fragments are in $\mathrm{kb}$. A: with the $6.1 \mathrm{~kb}$ fragment of sunflower as a probe. B: with $25 \mathrm{~S}$ rDNA as a probe. 
ments of 5.7 and $6.2 \mathrm{~kb}$ correspond to units designated as 8.8-8.8-9.4 and 9.2-8.8-10.2 and 9.6-9.6-4.3 types (fig 1A, 3A, 3B). TIh7 displayed variable length unit types according to the 8.3, 8.8, and $9.5 \mathrm{~kb}$ Hindll fragments, and the 4.2, 4.3, 9.4 and $10.2 \mathrm{~kb}$ Xhol fragments. The 5.2 and $5.8 \mathrm{~kb} E c o \mathrm{Rl}$ fragments and the 3.1 and $4.7 \mathrm{~kb} \mathrm{BamHI}$ fragments correspond therefore to 5 unit types (table III; results not shown).

In the 6 lines under study we constructed 13 unit types. All types existed as 2 forms depending upon the presence of the short $(2.45 \mathrm{~kb})$ or long $(2.6 \mathrm{~kb}) 25 \mathrm{~S}$ rRNA coding region. The complex rDNA diagrams obtained from these lines were, therefore, due to the presence of 2, 3 or more rDNA unit types in one line (table III; fig 2).

\section{Inheritance of ribosomal DNA polymorphisms}

In order to determine the number of loci, crosses were performed between lines St43 and TIh1, differing in their rDNA. The next gene ratio (backcross) was obtained with both St43 and TIh1.

\section{Sorting rDNA fragments in the [(St43 $\times$ TIh1) $\times$ St43] backcross}

The EcoRI profiles of St43, the hybrid, Th1 and 10 individuals of the [(St43 $\times$ Tlh1 $) \times$ St43] backcross displayed 4 classes of rDNA fragment combination (fig 4). The segregation for the 7.9, 5.7, 5.4 and $1.6 \mathrm{~kb}$ fragments was observed for 48 plants. The first hypothesis checked was to consider the $7.9 \mathrm{~kb}$ fragment as the allele of the block including the $5.7,5.4$ and $1.6 \mathrm{~kb}$ EcoRI fragments $[=5.7,5.4,1.6]$. The ratio $19: 29$ leads to the calculated $\chi^{2}$ for $(1: 1)$ of 2.08 , in agreement with the hypothesis; 19 segregating plants with the 7.9 only in comparison with the 29 plants carrying the [7.9] plus the $[5.7,5.4,1.6]$. However we rejected the hypothesis of 1 locus only because of the following observations: 1) we observed a disjunction between the 5.7 and 5.4 $\mathrm{kb}$ fragments (fig 4); 2) the 1.6 and $5.7 \mathrm{~kb}$ fragments cosegregated, and consequently belong to the same unit, previously recognized as the 10.8-ND-9.4 (table III; fig 4); and 3) we observed 4 classes of plants carrying a different set of rDNA fragments. Out of the number of plants studied, the equal frequency of 4 classes, ie 10 $[7.9], 19[7.9,5.7,5.4,1.6], 16[7.9,5.4], 3$ [7.9, $5.7,1.6]$ was rejected $\chi^{2}=15.8$. It is therefore likely that the 5.4 and $5.7 \mathrm{~kb}$ fragments correspond to different loci, [5.4] and [5.7] respective-
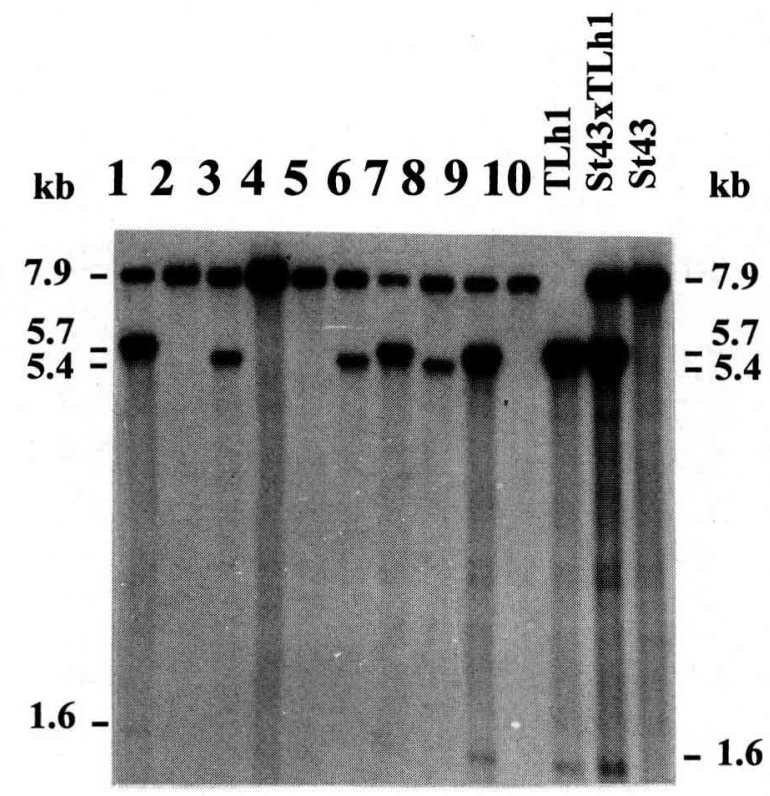

Fig 4. Hybridization profiles of DNAs restricted by EcoRI from St43, Tlh1, the hybrid and 10 (lanes 1-10) individuals of the $[(\mathrm{St} 43 \times \mathrm{Tlh} 1) \times \mathrm{St} 43]$ backcross, hybridized with $18 \mathrm{~S}$ rDNA as a probe.

ly. We also verified whether the 5.7, 5.4 and $1.6 \mathrm{~kb}$ fragments were transmitted together or independently in equal frequency. The higher frequency of the [5.4] (35/48) in comparison with the [5.7] (22/48) indicates that it is likely that 2 loci carried [5.4] while one carried [5.7]. We found a marked difference which favours the [5.4] in comparison with the [5.7 +1.6], 16 for 3 respectively, while they cosegregated in 19 plants. These results suggested that the St $43 \times$ TIh 1 plant, used as a female parent, carried 1 [5.4], 1 [7.9] and $1[5.7+1.6]$. The Tlh1 plant should carry 2 [5.4] and 1 [5.7 + 1.6]. Consequently we checked several hypotheses of 2 or 3 independent loci. Two hypotheses fitted the observed segregation. The 2 hypotheses imply 2 [5.4] and 1 [5.7] in TIh1 but they differ by postulating either 1 [7.9] and 2 nulli-alleles or 2 [7.9] and 1 nulli-alleles in St43.

\section{Sorting out of rDNA fragments in the [St43 $\times$ TIh1] $\times$ Tlh1 backcross}

The EcoRI profiles of St43, the hybrid, TIh1 and 10 individuals of the $[(\mathrm{St} 43 \times \operatorname{Tlh} 1) \times \operatorname{Tlh} 1]$ backcross are shown in figure 5 . The plants carrying the [7.9] were scored and the segregation was checked for the presence of 1 or 2 [7.9] loci. The calculated $\chi^{2}$ expected for 2 [7.9] was 1 for a 1:1 segregation, while it was $\chi^{2}=32$ for a 3:1 segregation, indicating that the [7.9] is located at 1 locus only. 


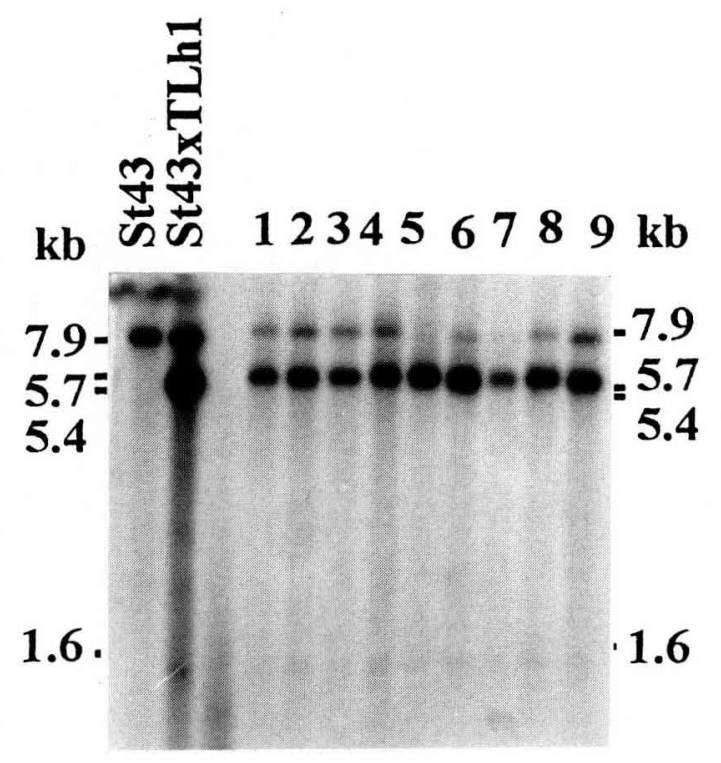

Fig 5. Hybridization profiles of DNAs restricted by EcoRl from St43, Tlh1, the hybrid and 9 (lanes 1-9) individual of the [(St43 $\times$ Tih1) $\times$ Tih1] backcross, hybridized with $18 \mathrm{~S}$ rDNA as a probe.

\section{Sorting rDNA fragments in the [Sk176b $\times$ TIh1) $\times$ TIh1] backcross}

The EcoRI profiles of Sk176b, the hybrid, T/h1 and 10 individuals of the backcross are shown in figure 6 . The segregation for the $6.2 \mathrm{~kb}$ fragment with the hypothesis of 1 locus was expected to be $1(+6.2)$ for $1(-6.2)$. We found $20(+6.2)$ for $28(-6.2)$, the calculated $\chi^{2}$ being 0.6 accepting the hypothesis of 1 locus only.
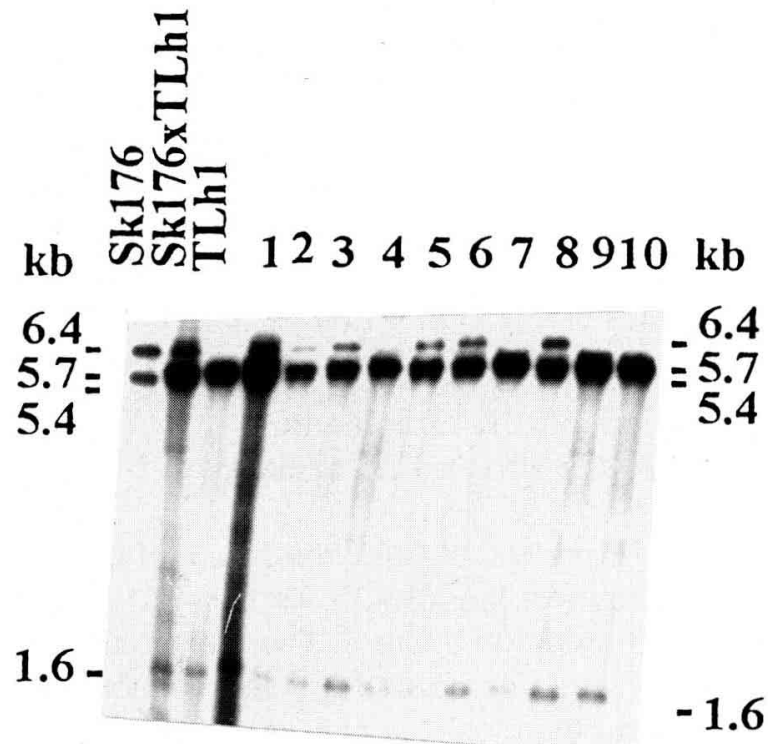

Fig 6. Hybridization profiles of DNAs restricted by EcoRI from St43, Sk176b, the hybrid and 10 individuals (lanes 1-10) of the [(Sk176b $\times$ TIh1) $\times$ TIh1] backcross, hybridized with the $8.2 \mathrm{~kb}$ entire rDNA unit as a probe.

\section{rDNA unit type segregation in haploid plants}

Among the segregant haploid plants we found the St43 type, the Tlh1 type and different combinations of the rDNA types. One corresponds to the 3 rDNA types present in the 2 lines, the individual being carefully verified for a hapioid state (fig 7, lane 4).

\section{In situ hybridizations}

Because we suspected different arrays of rDNA genes at every locus, we carried out in situ hybridization on both mitotic and meiotic chromosomes. We observed about 1000 pollen mother cell (PMC) nuclei for the 3 lines. The statistics on the signals are shown in table IV. For the 3 lines the common situation at the PMC stage was 2 signals of different intensities while the third signal was at a low frequency (fig 8). The metaphase of the St 43 haploid plant displayed only 2 signals but here the chromosomes were identified. Chromosome II carried the most intense and chromosome III the least intense signals (fig $8 \mathrm{C}$ ).

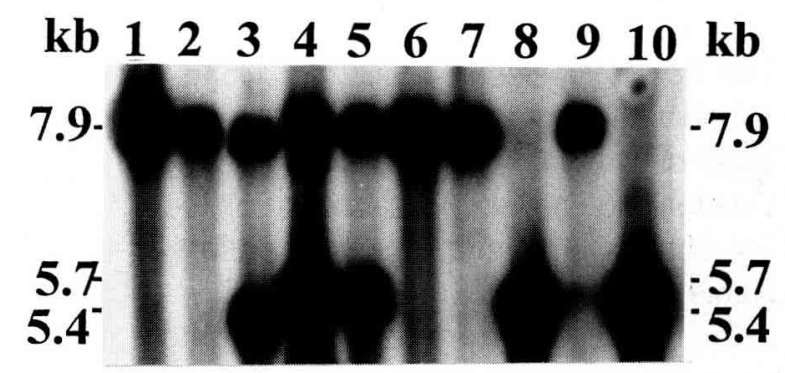

Fig 7. Hybridization profiles of DNAs restricted by EcoRl from 10 haploid individuals from the St $43 \times$ TIh 1 hybrid, hybridized with $18 \mathrm{~S}$ rDNA as a probe.

Table IV. Hybridization signals numbered on pollen mother cell nuclei for St43, TIh1 and Sk176b lines.

Line

Percentage of nuclei

Nuclei that display $x$ hybridization signals observed

\begin{tabular}{lcccccc} 
& 0 & 1 & 2 & 3 & \\
\cline { 6 - 7 } St43 & 24.6 & 17.1 & 55.6 & 2.7 & 1055 \\
TIh1 & 22.6 & 22.7 & 53.8 & 0.9 & 1059 \\
Sk176b & 28.2 & 17.5 & 53.4 & 0.9 & 1030
\end{tabular}




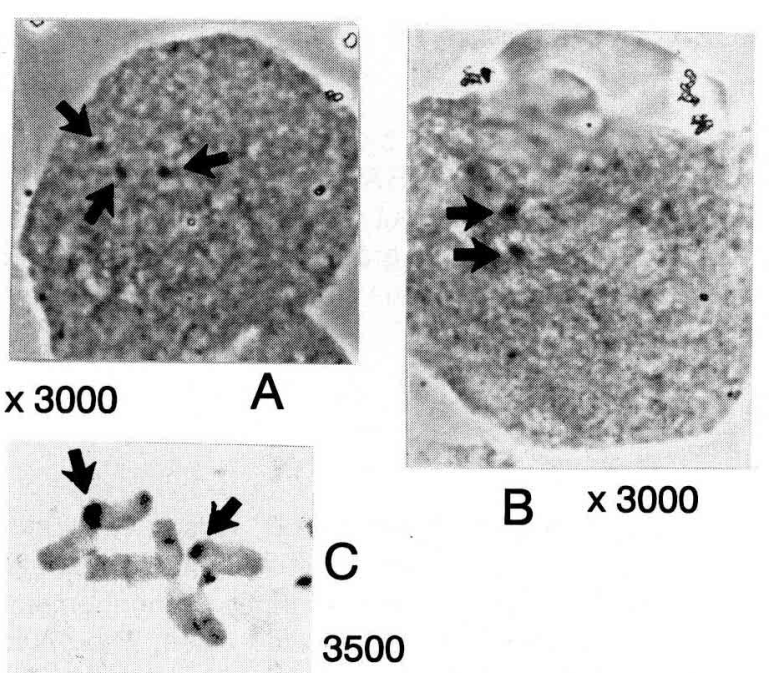

Fig 8. Hybridization of the $8.2 \mathrm{~kb}$ fragment as a biotinylated probe onto PMC chromosomes at the early prophase I stage. A: St43. B: TIht and C: onto mitotic chromosomes of the haploid plant from St43.

\section{DISCUSSION}

\section{rDNA organization and types}

Ribosomal DNA physical maps of several unit types have already been published for $P$ hybrida. Our results on the Tlv1 line (Mitchell) correspond to those of Waldron et al (1983). Taking into account the rDNA physical maps previously described, we agree with their EcoRI and Hinall restriction sites, but we found the $1.1 \mathrm{~kb} E c o R I$ fragment at the $3^{\prime}$ end of the 18 S rDNA. However we demonstrated the presence of the $1.1 \mathrm{~kb} E c o R I$ fragment in the transcribed spacer region and we recognized 2 unit types differing by the 2.6/2.45 kb EcoRl fragment. We studied the St43 line carrying 1 unit type of $11.4 \mathrm{~kb}$, posing the question whether the other unit types might be of the same length. The mapping of the BamHI-Hindll fragments in the non-transcribed region enables us to construct 2 main unit types with or without the Hindll sites, thus indicating the same length for all the unit types. The $2.4 \mathrm{~kb}$ fragment hybridizes with the entire flax rDNA unit as a probe and it is likely that it did not hybridize with the entire cereal rDNA unit used by Waldron et al (1983). The construction of the new 10.8-ND-9.4 unit type carrying the 5.7 and $1.6 \mathrm{~kb} \mathrm{EcoRI} \mathrm{fragments} \mathrm{was} \mathrm{possible} \mathrm{because}$ we observed the cosegregation of these fragments in the backcross (fig 4). More evidence to support the $11.4 \mathrm{~kb}$ length of unit types is that the
8.8-8.8-9.4 unit shows an obvious discrepancy concerning long $E c o R I$ and $X$ hol fragments. The total length of the unit is at least $9.4+1.2=$ $10.6 \mathrm{~kb}$ while the longest EcoRl fragment is $5.4 \mathrm{~kb}$. This is the reason for looking for missing fragments. These missing fragments would have been revealed with a homologous DNA probe. This probe could not be obtained from $\mathrm{J}$ Waldron, moreover our trials failed to reveal any rDNA clones in a lambda genomic library kindly given to us by $\mathrm{T}$ Holton (Calgene Pacific). We have recently found all these unit types distributed in 7 wild Petunia species (Kabbaj et al, 1994).

\section{Genetics of rDNA unit types and loci determination}

We propose that there are 3 loci for ribosomal DNA in the $P$ hybrida genome. The evidence of a possible third locus cannot formally be drawn from the plant material under study since we did not handle lines carrying 3 different unit types recognizable by RFLP. Conversely, the sorting out of the rDNA types in haploid plants clearly brought evidence for 3 loci since 1 individual displayed 3 rDNA types, knowing that the [5.7] and [5.4] segregated. This segregation is easily explained with the following distribution of the types in the lines. The presence of a nulli-rDNA allele in a line is not a frequent situation, but it is clearly established for St43 and St40. Consequently, we pose the question as to whether the St 43 and St40 lines have the same origin as the other lines.

On one hand, we suspected that 1 chromosome in the St43 line did not carry rDNA locus while the homologous chromosome in TIh1 carries either the [5.4] or the $[5.7+1.6]$. On the other hand, we did not suspect the [7.9] elimination because the seed set was normal in the hybrid. Nevertheless, the hypothesis of one 7.9 rDNA locus in St43 is not compatible with the results of the backcross [(St43 $\times$ Tlh1 1$) \times \mathrm{St} 43]$ which displayed 4 types of rDNA unit combinations, and the hypothesis of one $7.9 \mathrm{~kb}$ rDNA locus has to be rejected for this line. The hypothesis of two 7.9 rDNA loci explains the 4 types. We tried to assign the rDNA unit types and found 2 loci in every line (table III). It is clear that in lines Sk176b, Tlv1 and St40, which carry 3 unit types, we have to assign 2 unit types at 1 of the 2 loci, while in TIh7, 2 unit types have to be assigned at 2 of the 3 loci. 
Two Petunia chromosomes are good candidates for carrying ribosomal genes, since the II and III chromosomes carry large and small satellites respectively on the short arm. We effectively observed through in situ hybridization that the chromosomes carrying satellites also carry the ribosomal genes. It has been demonstrated that ribosomal genes are located within the satellite (Ingle et al, 1975). Two loci are therefore clearly assigned. However, the discrepancy between the segregation analysis and the in situ hybridization data remains to be explained for the St43 line. It is likely that the third locus carries no polymorphic unit type between the lines used in crosses. We have found another minor unit type of $11.6 \mathrm{~kb}$ present in every line. We propose here that the array of this unit type is located at the third locus*. We observed that the dihaploid lines TIh7 and TIh1 carry more unit types than any other lines, possibly indicating that some genomic rearrangement might have occurred during the haplo-diploidisation process.

$P$ hybrida was created 170 years ago by crossing several wild ecotypes most likely to belong to different species (Wijsman, 1982). It is likely, therefore, that the rDNA unit types found in 5 lines of the collection do in fact carry rDNA unit types from wild species. Consequently the relationship of the lines based on rDNA unit types has no evolutionary significance but it is informative for drawing the genealogical tree. When lines carry an identical unit type they must have a common ancestor, but if they do not carry a common unit type we cannot draw conclusions as to their genealogy.

We bring evidence of different unit types of Petunia ribosomal DNA. Their segregation in backcrosses appeared inconclusive for an accurate genetic analysis. The presence of 3 loci was demonstrated in a haploid progeny. The in situ hybridization data agrees with 3 loci. This fact underlines that segregation of a molecular trait in a F2 or in a backcross must be confirmed by another progeny and another method before definite conclusions are drawn. The rDNA unit types found in $P$ hybrida lines are now being researched in wild species.

\section{ACKNOWLEDGMENTS}

This work was supported by the 'Conseil Régional de Bourgogne' and by INRA 'AIP Recombinaison'. Thanks are due to $\mathrm{J}$ Delbut for his expertise in photography. $L$ Richardson is gratefully acknowledged for helpful reading of the manuscript.

\section{REFERENCES}

Arnheim N, Krystal M, Schmickel R, Wilson G, Ridder O, Zimmer E (1980) Molecular evidence for genetic exchanges among ribosomal genes on nonhomologous chromosomes in man and apes. Proc Natl Acad Sci USA 77, 7323-7327

Bernatsky R, Tanksley SD (1986) Toward a saturated linkage map in tomato based on isozymes and random cDNA sequences. Genetics 112, 887-898

Choumane W, Heizmann $P$ (1988) Structure and variability of nuclear ribosomal genes in the genus Helianthus. Theor Appl Genet 76, 481- 489

Cornu A, Farcy E, Mousset C (1989) A genetic basis for variation in meiotic recombination in Petunia hybrida. Genome 32, 46-53

Cornu A, Farcy E, Maizonnier D, Haring M, Veerman W, Geratz AGM (1990) Petunia hybrida. In: Genetic Map (SJ O'Brien, ed), Cold Spring Harbor Laboratory Press, NY, USA, 107-124

Doyle JJ, Dutertre M, Lafay JF, Roquebert MF, Brygoo $Y$ (1990) A molecular assesment of the position of Stilbothamnium in the genus Aspergillus. In: Modern Concepts in Penicillium and Aspergillus Classification (RA Samson, Pitt JI, eds), Plenum Press, New York, USA, 335-342

Ellis THN, Davies DR, Castleton JA, Bedford ID (1984) The organization and genetics of rDNA of rDNA length variants in peas. Chromosoma 91, 74-81

Ellis THN, Le D, Thomas CM et al (1988) 5S rRNA genes in Pisum, sequence, long range and chromosomal organization. Mol Gen Genet 214, 333-342

Goldsbrough PB, Cullis CA (1981) Characterization of the genes for ribosomal RNA in flax. Nucl Acids Res 9, 1301-1309

Ingle J, Timmis JN, Sinclair J (1975) The relationship between satellite DNA, ribosomal RNA gene redundancy, and genome size in plants. Plant Physiol 55, 496-501

Kabbaj A, Zeboudj F, Peltier D et al (1994) Variation and phylogeny of the ribosomal DNA unit types and 5 S DNA in Petunia jussieu: $P$ hybrida hort. rDNA

\footnotetext{
* Note added while the article was in press.

The article by Borisjuk et al (1994) [Borisjuk N, Borisjuk L, Petjuch L, Hemleben V (1994) Comparaison of nuclear ribosomal RNA genes among Solanum species and other Solanaceae. Genome 37, 271-279] has brought a correct explanation for the simultaneous presence of 2.6 and $2.45 \mathrm{~kb} \mathrm{EcoRl} \mathrm{fragments:} \mathrm{there} \mathrm{is} \mathrm{another} \mathrm{EcoRl} \mathrm{site} 0.15 \mathrm{~kb}$ far away from the one conserved in the $25 \mathrm{~S}$. This new site unique to the few Solanaceous species studied is also present in Petunia. Moreover this site is more or less methylated which leads to partial restriction. In consequence all the rDNA unit types which were revealed in our work are $11.6 \mathrm{~kb}$ long. Unfortunately any Petunia species was included in the study by Borisjuk et al (1994).
} 
units originated in several wild Petunia species. Genet Res Crop Evol (in press)

Levesque $H$, Vedel F, Mathieu C, de Courcel AGL (1990) Identification of a short rDNA spacer sequence highly specific of a tomato line containing Tm-1 gene introgressed from Lycopersicum hirsutum. Theor App/ Genet 80, 602-608

Maizonnier D (1976) Étude cytogénétique de variations chromosomiques naturelles ou induites chez Petunia hybrida Hort. Thèse Doctorat Sciences Naturelles, Dijon, France, 1-176

Maizonnier D, Moessner A (1979) Localization of the linkage groups on the seven chromosomes of Petunia hybrida genome. Genetica 51, 143-148

May CE, Appels R (1987) Variability and genetics of spacer DNA sequences between the ribosomalRNA genes of hexaploid wheat (Triticum oestivum). Theor Appl Genet 74, 617-624

Raquin C, Cornu A, Farcy E, Maizonnier D, Pelletier G, Vedel F (1989) Nucleus substitution between Petunia species using gamma ray-induced androgenesis. Theor Appl Genet 78, 337-341
Rocheford TR, Osterman JC, Gardner CO (1990) Variation in the ribosomal DNA intergenic spacer of maize population mass-selected for high grain yield. Theor Appl Genet 79, 793-800

Saghai-Maroof MA, Soliman KM, Jorgensen RA, Allard RW (1984) Ribosomal DNA spacer length polymorphisms in barley, mendelian inheritance, chromosomal location, and population dynamics. Proc Natl Acad Sci USA 81, 8014-8018

Santoni S, Bervillé A (1992) Characterization of the nuclear ribosomal DNA units and phylogeny of Beta $\mathrm{L}$ wild forms and cultivated beets. Theor App/ Genet 83, 553-542

Voronina M (1991) Sunflower karyograms. In: Proc of the First Sunflower Biotechnology Conference in Europe, Mittlewhir, France, 2

Waldron J, Dunsmuir P, Bedbrook J (1983) Characterization of rDNA repeat units in the Mitchell Petunia genome. Plant Mol Biol 2, 57-65

Wijsman HJW (1982) On the interrelationships of certain species of Petunia. I. Taxonomic notes on the parental species of Petunia hybrida. Acta Bot Neerl $31,477-490$ 